\title{
Elaborating the Role of Backbone Leadership Organizations in Sustainable Tourism Development: The Monongahela River Valley Coalition
}

\author{
Steven Selin \\ Division of Forestry and Natural Resources, West Virginia University, PO BOX 6125, Morgantown, \\ WV 26506, USA; sselin@wvu.edu; Tel.: +1-304-216-6399
}

Received: 1 June 2017; Accepted: 1 August 2017; Published: 3 August 2017

\begin{abstract}
Leadership has emerged as a central factor in sustainable regional development. Complex regional development initiatives need dynamic leaders to convene diverse stakeholders, sustain participation, leverage external resources, and achieve collective impact. This study researched the deeper meanings and application of backbone leadership using case study research examining a collaborative, regional initiative known as the Mon River Valley Coalition (MRVC). The MRVC is a regional and community-based economic revitalization program that promotes economic and environmental sustainability by capitalizing on the outdoor recreation and nature-based tourism potential of the Monongahela River. Through an inductive logic process, this research study analyzed the role and capabilities exhibited by backbone leaders associated with the MRVC. The data revealed that backbone leadership has been important to the cumulative success of the Monongahela River Valley Coalition. Study results highlight the backbone leadership roles and capabilities demonstrated by the leadership team both internally and external to the coalition. Sustainable development leaders work in uncharted waters-beyond the safe harbors of government, corporations, and nonprofit organizations. Research is needed that elaborates the integrative work that these sustainability leaders do. Studies such as this one can illuminate the pathway for those to follow.
\end{abstract}

Keywords: leadership; sustainable development; sustainable tourism; backbone organization; collective impact

\section{Introduction}

Leadership has emerged as a central factor in sustainable regional development [1,2]. Complex regional development initiatives need dynamic leaders to convene diverse stakeholders, sustain participation, leverage external resources, and achieve collective impact. Leadership is particularly critical in advancing rural regions that have experienced painful dislocation and transformation as a result of economic globalization [3]. The challenges of operationalizing sustainable development at a regional and place-based scale have been noted by a number of authors [1,4]. Sustainable development is a normative concept that involves the deliberative integration of economic, ecological, and social objectives. Bringing those regional aspirations into practice demands the contribution of enlightened, integrative leadership.

Rural regions looking to transform their economies and improve their quality of life have recognized the tourism sector as a catalyst for sustainable development [2]. The theory and practice of sustainable tourism development has emerged to address these global economic diversification challenges. However, the role of leadership continues to be a major challenge to these sustainable tourism initiatives. Economically lagging regions often lack the social and financial capital needed to fully implement sustainable tourism development initiatives. Wilson et al. concluded in a qualitative study of success factors in rural tourism development that a community approach—effective leadership, 
participation of local government, coordination between the business community and other sectors, and widespread community support-was necessary to achieve successful rural tourism development [5]. However, these are often the very governance attributes lacking in rural areas. This study specifically researches the leadership roles played by backbone leadership organizations to successfully coordinate participating agencies and achieving collective impact for sustainable tourism partnerships [6].

Despite the centrality of leadership to sustainable tourism development, previous leadership research has been insufficient to understand and explain the role of leadership in the multi-sector, cross-boundary, networked world of today [1]. Sustainable tourism leaders often work in uncharted territory-beyond the traditional boundaries of state, non-state, business, and auxiliary sectors. Leadership research is needed that emphasizes the integrative work these leaders do-convening diverse stakeholders, sustaining participation, leveraging external resources, and achieving collective impact. There is a lack of empirical data examining the role of leadership within the context of sustainable tourism development [2]. This line of research could inform the best practices for implementing effective tourism partnerships.

To address this empirical gap, this research explores the deeper meanings and application of leadership using case study research [7], examining a collaborative, regional initiative known as the Mon River Valley Coalition (MRVC). The MRVC is a regional and community-based economic revitalization program that promotes economic and environmental sustainability by capitalizing on the outdoor recreation and nature-based tourism potential of the Monongahela River [8]. Through an inductive logic process, this research study analyzed the roles and capabilities exhibited by backbone leaders associated with the MRVC. These research results were elaborated through an iterative process of incorporating field observations with leadership theory emerging from the environmental management, public administration, and philanthropy disciplines. Study results are relevant to global efforts to operationalize sustainable regional development at all geographic scales.

\subsection{Integrative Leadership Theory}

There is a vast scholarly literature on the topic of leadership. Historically, the leadership literature has focused on the personal qualities of effective leaders, primarily within organizations $[1,9]$. This research tradition is dominated by empirical work modeling what personality traits leaders embody to achieve organizational success. However, this large body of literature falls short in explaining the role of leadership in the complex, multi-sector, and cross-boundary world of implementing sustainable tourism at a regional scale.

Sustainable tourism development leaders work beyond the boundaries of traditional organizations, working in public settings where they have little formal authority to compel organizations and people to act. Instead, they employ a different set of roles and capabilities to convene diverse stakeholders, build a compelling vision, sustain participation, and achieve collective impact. More recent leadership research is beginning to examine the roles of leaders within the uncertain, complex, and integrated world of sustainable development and sustainable tourism.

A common theme running through the scholarly literature on sustainable development and sustainable tourism is the central role of inter-organizational collaboration in achieving collective impact on the ground $[3,10]$. Sustainable tourism development has been examined from the conceptual context of networks, collaborative governance, and partnerships $[8,10]$. For rural areas, especially, network and community-based governance models have gained primacy in scholarly and professional circles. This may be due to the fact that rural areas often feel marginalized from hierarchical government systems and major economic markets [11]. It is also likely that a collaborative approach to tourism governance is important to integrating the social, economic, and environmental considerations necessary to achieve the goals of sustainable tourism development [12]. Clearly, leadership is critical to facilitating this collaborative process-bringing parties to the table, sustaining participation, and moving the collaboration forward [13]. 
Our research was also informed by recent scholarship elaborating the principles of integrative public leadership. According to Morse, integrated public leadership is a process of, "developing partnerships across organizational, sectoral, and jurisdictional boundaries that create public value" [3] (p. 231). These boundary-spanning individuals and organizations serve a catalytic role of envisioning some larger public purpose and then enabling integrative partnerships to make progress towards that goal. This integrative public leadership role is similar to other scholarly treatments of leadership related to sustainable tourism. For example, McGehee et al., examining a set of rural tourism case studies, concludes that there is a strong need to move beyond business-focused approaches towards more inclusive governance frameworks [2]. This trend is also evident in the work applying collaborative governance processes to the sustainable tourism field [10] where it is inferred that collaborative leaders are needed to advance sustainable tourism.

Another stream of leadership research is coalescing around the concepts of "shared leadership" or community-based leadership $[1,2,14]$. Sustainable development and sustainable tourism demand leaders that can move beyond the boundaries of hierarchical organizations, beyond the limits of leader-follower roles, and work to catalyze and enable networks acting together. Kirk and Shutte describe this type of leadership as "connective leadership" which they describe as helping participants create and sustain a creative space where collective leadership can flourish [14].

These research findings suggest that leadership roles within sustainable development and sustainable tourism initiatives require people and organizations that have the singular capability to bring diverse sets of partners together and keep them together to create economic, social, and environmental impacts with lasting public value. Whether we describe this type of leadership as collaborative, integrative, shared, inclusive, or connective-there is overwhelming empirical and professional evidence that achieving the promise of sustainable tourism will require leaders exhibiting this set of competencies.

\subsection{Backbone Leadership Organizations}

This research study examines one form of integrative leadership gaining prominence in the scholarly literature, the role of "backbone organizations" in achieving collective impact emblematic of sustainable development and sustainable tourism initiatives [6]. The role of backbone organizations was elaborated in the philanthropy literature by Hanleybrown et al. in their seminal article examining the necessary conditions to achieve "collective impact" which they describe as highly-structured collaborative efforts that have achieved substantial impact on a large scale social problem [6]. The authors identified three pre-conditions necessary to achieving collective impact: (1) the presence of an influential champion; (2) adequate financial resources; and (3) a strong sense of urgency for change. Further, Hanleybrown et al. found that to create and sustain collective impact, sustainability initiatives often need a separate organization with the resources and skills to coordinate participating entities and serve as the backbone for the entire initiative [6].

In their study of backbone organizations, Hanleybrown et al. found that that these organizations pursue six different types of activities to support the overall goals of the partnership: (1) guide vision and strategy; (2) support aligned activities; (3) establish shared measurement practices; (4) build public will; (5) advance policy; and (6) mobilize funding [6]. Essentially, these were the common activities that backbone organizations did for their partnership. Backbone organizations also bring significant capabilities or resources to collective impact initiatives. According to Hanleybrown et al., effective backbone organizations bring their social networks, their access to policy-makers and investment capital, their vision and strategy, and their spirit of optimism and persistence to the partnerships they serve [6].

Thus, this paper asks three research questions: How important are backbone organizations to the success and collective impact resulting from sustainable tourism partnerships? What roles do backbone organizations play in providing integrative leadership to sustainable tourism partnerships? What capabilities/resources do backbone organizations bring to sustainability initiatives? These questions 
drove the research objective of analyzing the role that backbone leadership organizations play in sustainable tourism partnerships.

\section{Methods}

This research employed an embedded case study research design $[15,16]$ to analyze the role of backbone organization leadership with the Monongahela River Valley Coalition (MRVC). The researcher was familiar with the MRVC, having served as a program coordinator with the Monongahela River Town Program for two years and in that role participating in many of the formative meetings that led to the establishment of the MRVC. Dredge et al. [15] note the strengths of this embedded research design, "Reflexive engagement in wicked problems closes the gap between research and practice, increasing the potential for knowledge sharing." After stepping down from the program coordinator position, the researcher was able to use personal knowledge, social networks, and accumulated program material to conduct this embedded case study research design [7].

This case study research used a multiple-methods approach to address the research objectives. Data collection included stakeholder interviews, document analysis, and personal observation. Documents analyzed included MRVC meeting minutes, agendas, and website; newspaper articles; and MRVC reports and publications. These secondary materials were used to construct a developmental history of the MRVC. Using criterion-based and snowball sampling methodologies, community leaders of the MRVC were interviewed, as well as several independent regional leaders familiar with the MRVC. In addition, both members of the leadership team were interviewed. Semi-structured, open-ended interviews were completed during the spring and summer of 2015 with study respondents, averaging $45 \mathrm{~min}$ in length. In total, 10 MRVC community leaders were interviewed as well as the two backbone leaders and two other independent regional leaders making a total of 14 interviews. The interview guide included several open-ended leadership questions related to the project value added by the leadership team, what roles and tasks the leadership team performed in support of the MRVC, and what capabilities and resources the leadership team brought to the MRVC. A final leadership question asked what if the leadership team stepped away from the project? What would the impact be and how would the MRVC adjust to this transition? Interviews were audio-recorded and professionally transcribed verbatim. Data was hand-coded and sorted into meaning analytic units using NVivo 10 (QSR International, Doncaster, Australia).

\section{Results}

\subsection{Developmental History of the Monongahela River Valley Coalition}

To unravel the deeper meanings associated with elaborating the role of backbone organization leadership for the MRVC, it is useful to analyze the events and circumstances surrounding the organization's evolution. This developmental history was constructed by examining primary documents, such as meeting minutes, as well as information available through published MRVC reports [17].

The story of the Monongahela River Valley Coalition (MRVC) begins with the Monongahela River and the River Town Program. The Monongahela River is a 130 mile long river located on the Allegheny Plateau in Northwestern West Virginia and Southwestern Pennsylvania in the United States (see Figure 1). The "River Towns" of the Monongahela River Valley were founded upon the power of the river to transport raw materials and people to industrial centers, like Pittsburgh, or the western frontier. Until the 1960s, these communities prospered, supplying Pittsburgh with raw materials to support a burgeoning steel industry. The post WWII collapse of the US steel industry led to systemic job and population loss from these communities, leaving historic riverfronts and buildings vacant and shuttered [18]. Many river communities lost up to $50 \%$ of their population, as younger residents moved to more prosperous regions of the United States. In many ways, the Monongahela River Valley epitomized the industrial decline of what became well known as the "rust belt" region of the United States. A greying population and high unemployment has persisted into the twenty-first century 
despite the intervention of numerous regional economic revitalization programs funded by the federal and state governments.

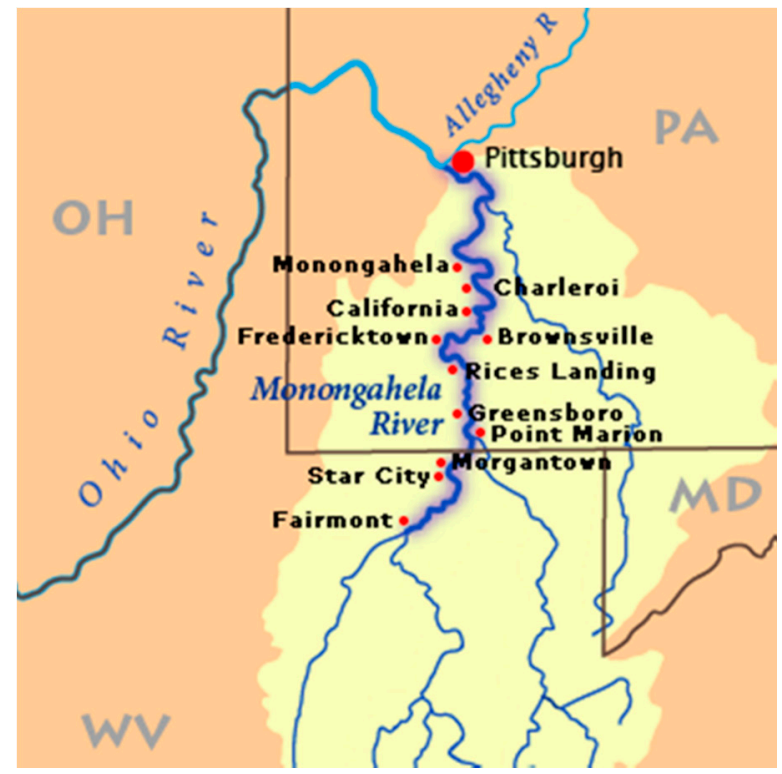

Figure 1. The "River Towns" of the Monongahela River.

Interestingly, the tourism and outdoor recreation sector is emerging as a potential catalyst to the sustainable development of the region. Residents and visitors are re-discovering the Monongahela River not only as an industrial corridor, but as a natural and cultural asset, worthy of protection and stewardship. The "River Town Program" has capitalized on this growing public recognition of the Monongahela River as a recreational and tourism asset. Initiated in 2010, the lineage of the River Town Program can be traced to community revitalization programs, such as Main Street, Elm Street, and the National Trust for Historic Preservation's community-based tourism program with their shared values of self-help, partnerships, incremental change, asset-building, and place-making_all core attributes to sustainable development initiatives globally.

The River Town Program was initiated and guided by two community and economic development consultants with over 50 years of professional experience between them. Both of these consultants have considerable experience working with community development projects in the greater Pittsburgh and Southwestern Pennsylvania region. This experience also included leadership work with a number of sustainable tourism partnerships, including the Trail Town Program and the National Road Heritage Corridor. This community development team has played a coordinating and backbone leadership role of the River Town Program and MRVC since their inception through the present day, and will hence be called the leadership team.

The River Town Program is guided through a community-based approach by which worthy local projects are identified and implemented. The River Town Program works in communities where they are invited, presently in 11 river communities in Pennsylvania and West Virginia (see Figure 1). Once formally invited, community members assess their own community and riverfront through the eyes of a visitor, considering strengths, weaknesses, and opportunities. The leadership team provides technical assistance and meeting facilitation throughout this process. Once this assessment is completed, community action teams are formed. The action teams identify short-term, mid-term, and long-term projects they want to accomplish. These projects typically include amenity improvements such as: enhanced riverfront parks and marinas, riverside walking and biking trails, public art, wayfaring signing, riverfront events and festivals, and branding and promotional campaigns. Benedum Foundation funding for the River Town Program supported community participation for three years, 
after which communities "graduate" and are encouraged to find other sources of funding to accomplish their River Town goals [19].

One of the goals of the River Town Program has been to foster greater regional collaboration among river towns. While many projects are community-specific in nature, a growing number are regional in scope. For example, participating river towns have collaborated to develop a regional marketing campaign around the theme of, "Come Down to the River and Play". In addition, the River Town Program began to convene quarterly meetings of community action team members to identify and implement regional projects that could collectively benefit communities along the Monongahela River. As before, these regional meetings were convened and continue to be facilitated by the leadership team.

Monongahela River Valley Coalition

By the summer of 2013, the work of the River Town Program and its potential to foster sustainable economic revitalization of the Monongahela River Valley had come to the attention of elected officials at the county and state level. A delegation of River Town stakeholders traveled to the state capital of Harrisburg to meet with state legislators to encourage them to financially support identified River Town projects. The River Town advocates were encouraged to get organized as a regional interest group and develop an action agenda for the Monongahela River Valley that capitalized on the outdoor recreation and heritage tourism potential of the Monongahela River and the economic benefits that might be realized.

In September 2013, a regional coalition meeting was convened at California University of Pennsylvania and facilitated by the leadership team. The meeting was attended by 38 municipal and civic leaders from all the affected river towns-mayors, Borough managers, city council members, chamber of commerce directors, business owners, tourism associations, and other concerned private citizens. Most communities participating were either presently engaged in the River Town Program or were recent graduates of the program. In addition, there were representatives from several universities, regional economic development authorities, county commissions, and local and regional planners. River Town stakeholders were encouraged by elected officials attending the meeting to get organized as a region and develop a prioritized list of tourism enhancement projects they could share with other communities, share with legislators, and seek funding to implement. The coalition present at the first meeting agreed to meet every other month to develop this regional action plan [17].

This regional coalition met twice more in the fall of 2013 to develop a regional action plan. Meetings were convened and facilitated by the leadership team. Each participating river town generated a list of prioritized projects that would attract visitors and businesses and contribute to economic revitalization. Sample community-based projects included improving boat launches, extending riverside walking and biking trails, wayfaring sign programs, streetscape improvements, and enhancing community branding and marketing efforts. In addition, several regional projects were identified, including developing a regional governance "entity" for the purposes of identifying funding opportunities, and sharing expertise and resources among participating communities. In addition, the coalition also identified the need to develop a "brand identity" for the Monongahela River Valley region, along with a comprehensive plan to develop and market its cultural, recreation, historic, and natural resources.

By January 2014, these regional tourism enhancement priorities had been written up by the leadership team and published in an action agenda that has been shared widely with potential funding agencies and posted to the MRVC website [17]. The regional coalition also decided to create several sub-committees which included a branding and marketing committee and also a College task force of the participating universities. Plans were made for the MRVC to meet quarterly to focus on implementing their regional action agenda.

Since the winter of 2014, MRVC stakeholders have been implementing their action agenda through a number of community-based and regional projects. The branding and marketing committee has 
developed a "Come down to the River and Play" marketing campaign and slogan for the MRVC. Using this slogan, a coordinated set of 17 river town tourism events were held on Memorial Day weekend in 2015 in which seven towns participated. This coordinated series of events included community festivals, farmer's markets, tours of historic homes and industrial sites, and kayak and bicycle tours, to name a few. Another focus of the MRVC has been on small business development. A business plan competition known as the SMAART initiative, or the Sustainable Marketplace for Art, Artisans, Recreation, and Trending, provided a $\$ 10,000$ cash prize to the winning three business plans [20].

The MRVC continues to meet quarterly as an entire group, facilitated by the leadership team. Sub-committee groups meet in between these quarterly meetings. There is discussion of how to best build a sustainable future for the MRVC, especially when the foundation support for the River Town Program ends or when the leadership team moves on to other projects or regions. Alternative governance structures are being explored.

\subsection{MRVC Community Leader Interviews}

\subsubsection{Value of Backbone Leadership}

Community leaders interviewed were unanimous in their thinking that the leadership team has added value to the collective impact of the MRVC. A number of participants interviewed felt that, without the sustained contribution of the leadership team, the River Town Program or MRVC would never have come to fruition. "Those two have been the driving force keeping this thing together. If they weren't involved, I don't see this happening." These sentiments were echoed repeatedly by MRVC participants.

Why was the role of the backbone leaders important to the success of the MRVC? Further probing revealed the reasons for this broad sentiment. Many community leaders were participating in the MRVC in a voluntary, community service capacity because they cared about the future of their community and the Monongahela River region. For many, participating in MRVC meetings was community service above and beyond other professional, community, or family responsibilities. Thus, a common explanation for the importance of the leadership team to the MRVC was responses like, "We all leave the room. If there's not a point person moving this down the road, it's not happening. They've stuck with it." Or, in a similar vein, "Everybody's got jobs. They're doing it because they care about their community but when they walk out of that room, they've got to go earn a living." Especially in rural communities, such as Mon river towns that lack the social capital to send professionals to planning meetings such as the MRVC, the leadership team has played a significant role in convening interested citizens and sustaining their participation in ways that translated into collective impact.

Backbone leadership analogies were woven throughout the community leader narratives. There were references to controllers, conductors, captains, and engineers. Sometimes, respondents even combined their comparison such as this, "You need someone devoted to keeping the wheels turning and the boat sailing down the river." Or, similarly, "We need the conductor to keep us on track." Whatever the analogy, there was almost unanimous agreement that the role of the leadership team was important to the success of this type of rural-based, sustainable tourism partnership.

\subsubsection{Backbone Leadership Roles}

Another set of interview questions probe the set of backbone leadership roles played by the leadership team or job tasks they've performed in facilitating the work of the MRVC. In short, what do backbone leaders do to execute their function? In analyzing the qualitative data, leadership roles were grouped into two logical categories: internal roles occurring within the MRVC organization and external roles occurring outside of the MRVC organization. Internally, one of the most important roles played by the leadership team was empowering local leaders. This is not surprising given the community-based focus of the MRVC with its community and regional action team governance structure. This role was expressed most forcefully by members of the leadership team. "We have to constantly be pulling in 
new engagement or giving assignments, adding value, expressing gratitude." The future survival of the MRVC depends on empowering these local leaders. "Unless you have community buy-in, when the organizers walk out, there goes the project. At the grassroots level, people have to recognize the value of this and want it to happen in their community." Again, colorful analogies were used to describe this role-in this case military and parenting. "If we're not building, if the corporals aren't building privates." And, "Then you have to get your kids up on their feet enough, so you don't have to keep paying their bills or finding them money."

Another important internal role played by the leadership team was guiding the collective vision/strategy of the MRVC. This was a challenging role at the onset for the MRVC. Community members tended to focus their attention on the fortunes of their own community and initially struggled to appreciate the value of working together regionally to advance the fortunes of all participating river towns. According to one leadership team member, "We try to help them reach their community goals and they have to assimilate the goal and purpose of our [regional] organization." The MRVC has accomplished this strategy by supporting aligned activities such as the community and regional action team strategy. Community members tended to speak of this set of roles as helping to keep them focused and directed. Again the analogies emerged. The leadership team helped participants to: "Zero in on what's important." "Making sure things stay on track." Keeping the cat's herded which isn't always easy?" "Keeping everyone's eye on the ball."

The leadership team also played an important role in connecting people to resources, or as one participant described it, a "resource broker" role. A driving force behind the success of the MRVC has been the growing realization that the river towns can accomplish more as a region than they can by working independently. As one leadership team member stated, "Bringing together a larger body is a better tool when we're trying to drive grant money to a project-multiple communities, larger impact, and greater return on investment. It only made sense to bring together these river towns." It was easier for the leadership team to play this resource broker role once the river towns were coordinating their efforts regionally. One participant observed that the resources being brokered were not just about money. "Those external resources they're connecting people to are sometimes about money, but other times are about information, power, and access." For river towns conditioned by years of being marginalized-geographically and economically—the leadership team played a significant role in connecting these rural communities to external resources that could support their economic development aspirations.

Finally, a number of day-to-day project management roles have been filled by the leadership team. This would include the roles of convening multi-sector partners, meeting facilitation, internal communications, and report and grant writing. Participants had various compelling ways of describing these multiple roles. One described the leadership team as the "social glue" of the MRVC. "It's a lot like glue. They're willing to put in the effort. What night can we get together?" Other participants described the leadership team's strategy of phone calls. "You've got to have someone that's making the phone calls." Or, "If I don't send it, they're calling me to remind me." There was also the observed strategy of the "gentle nudge." "They have the ability to gently push. It's hard to get peoples' time. They have a soft, gentle nudge. Can we get together?" Finally, report and grant writing roles were other value-added tasks mentioned by MRVC participants. "They're the ones writing the grants. "Their expertise in grant writing has been vital." These were the suite of internal leadership roles played by the leadership team that community leaders felt were indispensable to the success of the MRVC.

Externally, the leadership team has played a significant role in facilitating many forms of external project communication to advance the interests of the MRVC. Much of this external communication has been focused on the goal of promoting the MRTC regionally and nationally. A broad goal of this external communication has been to build public support for the MRVC and its sponsored activities. As described by a leadership team member, "We're able to hold them up. This is a model. This coalition. Keeping us in the eyes of the public." The leadership team has used its vast professional and civic networks to broker financial and informational resources to the participating river towns. These social 
networks have allowed the leadership team to leverage external funds to support MRVC projects from a number of sources in county and state government, the corporate sector, and the philanthropic community. The leadership team has been very successful in reaching out to state elected officials and advocating for MRVC projects. According to one state official, "There's a political play that has to happen here. This coalition makes us [politicians] cognizant of the fact they need to stand up and say, here's what I did for you." The leadership team has also successfully leveraged local and statewide media coverage of recreation opportunities along the Monongahela River. For example, a continuing series of articles in the Keystone Edge online magazine has elevated the Mon River region as a travel destination statewide [18]. For their part, MRVC participants are appreciative of these external communications roles played by the leadership team. "They're very good at getting out there and finding the tools that they need to keep us moving forward."

\subsubsection{Backbone Leadership Capabilities}

While the previous section focused on what roles backbone leaders play, this section focuses on the capabilities of backbone leaders. In other words, what resources do backbone leaders bring to the sustainability partnerships they serve? Internally, MRVC participants identified a number of capabilities that allowed the leadership team to be effective in supporting the MRVC. First, community leaders pointed to a number of personality characteristics they felt were important to leadership effectiveness. These included, in no particular order, a sense of optimism and persistence. One participant described the leadership team as "pit-bulls" who refused to take no for an answer. Others described them as resourceful. "They're very resourceful and that's a wonderful thing." Another community leader lauded their affable qualities. "They can talk to anyone, very down to earth, you have to like them." One of the representatives of the smaller river towns was impressed with how inclusive they were. "It takes a special personality and leadership to make small communities feel included and really needed."

Finally, several participants attributed the capabilities of the leadership team to accumulated knowledge and experience. "Their knowledge and experience is priceless. They've done it." Knowledge and experience also contributed to a stocked toolbox of tourism marketing best practices, as well as public facilitation strategies. According to one participant, "All the acronyms they throw out. Most of the time I don't know what they're talking about!"

Externally, the capabilities of the leadership team kept coming back to one critical factor, their existing professional, political, business, and civic networks. Their project role as a resource broker, connecting people to resources, was explained best by their extensive social networks. "They're connected, fully aware of all the programs and services that are at our disposal". Or, "They've been in this business a long time. They have all the contacts that most of us don't know". These social networks gave the leadership team enviable access to investment capital, political capital, and media capital. "They know what money's available". Finally, several community leaders were also struck by the broad or integrated perspective that the leadership team brought to the MRVC. "They're people who have a broader perspective of community development. The biggest asset they bring to the table."

\subsubsection{Leadership Transition and Alternatives}

Several interview questions also probed the important questions of MRVC sustainability. How would the coalition adapt to the inevitable day when the leadership team moved on or start-up funds from the philanthropic community were no longer available? It became quite clear through these interviews that many community leaders had grown accustomed to the guidance provided by the leadership team. When asked what the greatest potential threat was to the future success of the MRVC, a common answer what this: "One of the biggest threats to the MRVC is that system leadership will go away and there's no replacement." For their part, the leadership team was well aware of this potential threat and were taking steps to prepare for this eventuality. "It's about the communities going back and pushing forward on the action plan. They have to take ahold of that plan. When we're not there 
saying, OK, come on, let's go. At some point, we'll be stepping back and moving other people into meeting leadership roles."

Many of the community leaders were self-aware enough to realize that any MRVC leadership or governance alternative would likely involve a replacement strategy for the current leadership team. They seemed to intuitively know that they needed a backbone leadership organization to sustain the success of the MRVC. "Somebody has to be paid and responsible to do it every day." At the time of these interviews, considerable dialogue centered on how to finance an eventual replacement for the current leadership team. Several different governance alternatives were being debated. One financing proposal discussed during the interviews was for participating county governments to pool resources to hire a backbone leadership organization. "Hoping the counties will fund a Mon River person to be the controller for this thing." Another financing alternative articulated by several community leaders was a pay-as-you-go approach where participating communities would pay an annual fee, perhaps graduated to their population, into a pooled fund to support the work of a backbone organization. "Perhaps a pay-as-you-go system where communities pay a fee to hire a regional coordinator." It should be noted that several representatives of smaller river towns expressed concerns that a pay-as-you-go system of financing would tend to favor the larger communities.

\section{Discussion}

The data revealed that backbone leadership has been important to the cumulative success of the Monongahela River Valley Coalition (MRVC). Following an inductive reasoning logic, this qualitative research study sought to elaborate the roles and capabilities of backbone leadership through an iterative process of learning from previous literature and integrating empirical evidence from this case study research. While the purpose here is not to generalize to a larger sample of sustainable tourism or sustainability initiatives, this qualitative research will inform future researchers to do so. The express purpose of this empirical research has been to reveal the deeper meanings of backbone leadership as interpreted through the eyes of the people most closely associated with it.

Based upon the research evidence, we can elaborate the roles and capabilities of backbone leadership for the MRVC (see Figure 2). The left column identifies those backbone leadership roles and capabilities that are internally focused. That is, they play out within the MRVC organization. The right column identifies those backbone leadership roles and capabilities that reveal themselves outside of the MRVC organization. Figure 2 illustrates that, at least with the MRVC, backbone leaders have played a significant role in coordinating the collective efforts of participating communities and other entities. These leadership roles have ranged from envisioning the nascent River Town Program through securing the original Benedum Foundation grant that jumpstarted the River Town Program through a central project management role to the present day.

Community leaders were unanimous in their agreement that the leadership team was critical to the success of their collective venture and that future success would hinge on replacing those backbone leadership roles if the present leadership team moved on. The challenge, of course, especially in economically-lagging regions of the world, is how to finance this backbone leadership role. It will likely take a "community approach" with financial contributions from multiple sectors to sustain the type of backbone leadership needed to achieve collective impact.

The tabular depiction of backbone leadership in Figure 2 is a simplification of how backbone leadership actually unfolds in the dynamic system of sustainability partnerships. One of the signature roles of backbone leaders from Figure 2, that of a resource broker-connecting people and resources-clearly blurs the boundaries between internal and external leadership roles. The blue arrows in Figure 2 illustrate the dynamic and interactive character of internal versus external leadership roles and capabilities.

Figure 2 elaborates backbone leadership roles developed within the context of a coalition of rural communities with limited social capital. The robust set of leadership roles and capabilities described in Figure 2 are perhaps most generalizable to sustainable tourism partnerships striving to diversify 
the economies of lagging rural regions of the world. It would be interesting to compare the roles elaborated here to backbone leadership roles elaborated in urban regions or in regions characterized with higher levels of social capital. Note that the backbone leadership roles developed here are not necessarily discipline-specific. The leadership roles and capabilities described in Figure 2 may be applicable to other disciplines beyond that of sustainable tourism. Clearly, future research is needed to analyze the role of backbone leadership across different contexts: geographical, economic, rural-urban, and cultural.

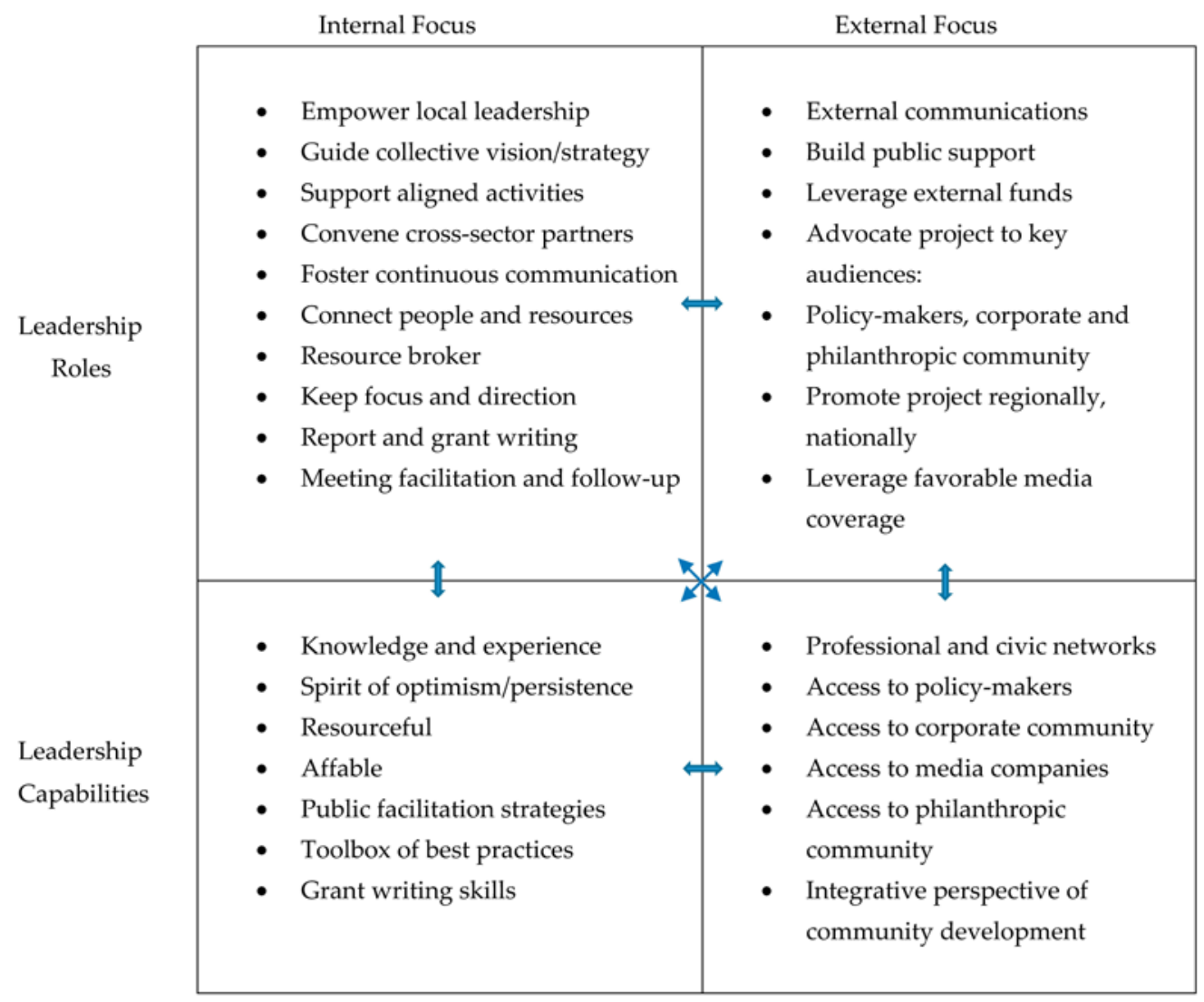

Figure 2. MRVC backbone leadership roles and capabilities.

\section{Conclusions}

These study results deepen our collective understanding of how integrated public leadership contributes to advancing sustainability initiatives. This research demonstrates how backbone leaders play a number of critical catalytic roles such as envisioning some larger public purpose and then enabling the integrated partnerships needed to make progress towards that vision. Future research is needed that analyzes the role of backbone and integrated public leadership across a diverse set of sustainable tourism partnerships.

A number of research designs are needed to extend and deepen the work described here. This case study research could be expanded to include multiple leadership case studies across different contexts, similar to the work of McGehee et al., with their multiple case study design [2]. It would also be instructive to analyze cases of tourism partnership failure and the roles that backbone leadership either did or did not play. The role of leadership within sustainable tourism or sustainability partnerships could also be examined profitably though the application of social network analysis [21]. Social network analysis would allow the empirical investigation of the social structures that define sustainability partnerships and roles that different social actors play within that social structure. From this study, 
we can hypothesize that the leadership team from the MRVC would occupy a central node in a social network map of the MRVC.

This exploratory research confirms the need to more deeply understand and operationalize emerging leadership approaches. Sustainable development leaders work in uncharted waters-beyond the safe harbors of government, corporations, and nonprofit organizations. New leadership models are needed that fully explain the integrative leadership needed to achieve collective impact across the sustainable development movement. This is especially true with initiatives struggling to lift lagging rural regions of the world. Studies, such as this one, can illuminate the pathway for those to follow.

Conflicts of Interest: The author declares no conflict of interest.

\section{References}

1. Horling, I.; Padt, F. Leadership for sustainable regional development in rural areas: Bridging personal and institutional aspects. Sustain. Dev. 2011, 21, 413-424. [CrossRef]

2. McGehee, N.; Knollenberg, W.; Komorowski, A. The central role of leadership in rural tourism development: A theoretical framework and case studies. J. Sustain. Tour. 2015, 23, 1277-1297. [CrossRef]

3. Morse, R. Integrative public leadership: Catalyzing collaboration to create public value. Leadersh. Q. 2010, 21, 231-245. [CrossRef]

4. Quental, N.; Lourenco, M.; da Nunes Silva, F. Sustainable development policy: Goals, targets, and political cycles. Sustain. Dev. 2011, 19, 15-29. [CrossRef]

5. Wilson, S.; Fesenmaier, D.; Fesenmaier, J.; van Es, J. Factors for success in rural tourism development. J. Travel Res. 2001, 40, 132-138. [CrossRef]

6. Hanleybrown, F.; Kania, J.; Kramer, M. Channeling change: Making collective impact work. Stanf. Soc. Innov. Rev. 2012, 10, 1-9.

7. Yin, R. Case Study Research: Design and Methods, 5th ed.; Sage Publishing: Los Angeles, CA, USA, 2015.

8. Baxter, L.; Malik, J. River Town Program marries outdoor recreation, economic development, and conservation. River Manag. Soc. J. 2013, 26, 20-21.

9. Baumgartner, R. Organizational culture and leadership: Preconditions for the development of a sustainable corporation. Sustain. Dev. 2009, 17, 102-113. [CrossRef]

10. Hall, M. A typology of governance and its implications for tourism policy analysis. J. Sustain. Tour. 2011, 19, 437-457. [CrossRef]

11. Hall, P.; Stern, P. Reluctant rural regionalists. J. Reg. Stud. 2009, 25, 67-76. [CrossRef]

12. Erkus-Ozturk, H.; Ayda, E. Environmental governance for sustainable tourism development: Collaborative networks and organization building in Antalya tourism region. Tour. Manag. 2010, 31, 113-124. [CrossRef]

13. Ansell, C.; Gash, A. Collaborative governance in theory and practice. J. Public Adm. Res. Theory 2008, 18, 543-571. [CrossRef]

14. Kirk, P.; Shutte, A. Community leadership development. Community Dev. J. 2004, 39, 234-251. [CrossRef]

15. Dredge, D.; Hales, R.; Jamal, T. Community case study research: Researcher operacy, embeddedness, and making research better. Tour. Anal. 2013, 18, 29-43. [CrossRef]

16. Wray, M. Drivers of change in regional tourism governance: A case analysis of the influence of the New South Wales government, Australia, 2007-2013. J. Sustain. Tour. 2015, 23, 990-1010. [CrossRef]

17. Monongahela River Valley Coalition. Capturing the Opportunities of the Monongahela River Valley Plan. Available online: http://monrivercoalition.org/wp-content/uploads/2015/11/ CapturingopportunitiesMonRiverValley_140502.pdf (accessed on 4 November 2013).

18. Parker, A. The Monongahela: River of Dreams, River of Sweat; The Pennsylvania State University Press: University Park, PA, USA, 1999.

19. Pennsylvania Environmental Council. River Towns Annual Report. Available online: http://pecpa.org/wpcontent/uploads/River-Towns-Report-2014.pdf (accessed on 25 April 2014). 
20. Duchene, W. Rebirth on the Monongahela River. Keystone Edge. Available online: http://www. keystoneedge.com/features/monrivervalley043015.aspx (accessed on 30 April 2015).

21. Fliervoet, J.; Geeling, G.; Mostert, E.; Smits, A. Analyzing collaborative governance through social network analysis: A case study of river management along the Waal River in The Netherlands. Environ. Manag. 2016, 57, 355-367. [CrossRef] [PubMed] 